\title{
Rethinking the "Slaves of Salaga": Post-Proclamation Slavery in the Gold Coast (Colonial Southern Ghana), 1874-1899
}

\section{Kwabena O. Akurang-Parry}

Unfree labour migration continued in colonial Africa at a time when the European colonial authorities were encouraging the use free labour to sustain burgeoning colonial economies. This paradoxical situation was due to contradictions in colonial policy and practice. Above all, the evanescent nature of colonial slavery abolition explains the continuity in unfree labour forms in the post-proclamation period. ${ }^{1}$ This study examines a major source of post-proclamation unfree labour in the Gold Coast colony and protectorate? : the "slaves of Salaga." It complements Paul Lovejoy and Marion Johnson's respective studies of the Salaga commercial emporium. ${ }^{4}$ I argue that the British defeat of the Asante in 1873-74 that ended Asante hegemony over Salaga, and the subsequent British abolition of slavery in the Gold Coast in $1874-75^{5}$ did not interrupt the Salaga slave supply to the Gold Coast. ${ }^{6}$ In this study, Salaga trading axis refers to all the trading centers north of Asante, including Salaga proper, Bontuku, Nkoranza, Kintampo, Atebubu, and Kete-Krakye. ${ }^{7}$ Overall, a spate of studies has revealed that slaves obtained from the Salaga trading axis formed the bulk of slaves in the precolonial Gold Coast. ${ }^{8}$ What this study seeks to do, and which has not been clearly rendered in the existing literature, ${ }^{9}$ is to show that the same phenomenon continued in the post-proclamation Gold Coast. Additionally, the study explores an aspect of Ghanaian history that has not gained the attention it deserves: the trade between the Gold Coast, specifically, the Accra-Cape Coast-Elmina region and the Salaga trading axis in the nineteenth century. Also, I show that until the 1880 s, slaves from the Salaga trading axis were exported alongside wage labourers to other colonial enclaves in Africa. This shows that the export of slaves from the Gold Coast lasted longer than previously thought. ${ }^{10}$ Complementing Claire Robertson's case study of post-proclamation female slavery in Accra, ${ }^{11}$ I provide insights into the social features of post-proclamation slavery and legal nuances that underscored the administration of the abolition laws.

Lovejoy, using the Salaga kola trade as a unit of analysis in his revision of Karl Polanyi's "ports of trade" paradigm, concluded that "the Salaga market began to disintegrate in the $1870 \mathrm{~s}$, the consequence of a serious crisis in 187374." 12 His conclusion is based on the British defeat of the Asantes in 1873-74 and the fact that the people of Salaga proper took advantage of that defeat and rebelled against Asante hegemony. Lovejoy shows that the 1873-74 crisis devastated the Salaga kola trade, but does not evaluate the impact of the crisis on 
the Salaga slave trade. Indeed, it was the kola supply regions to the south of Salaga that were affected by the crisis of 1873-74, but not the regions to the north that served as the main source of slave supply to the Salaga slave trading emporium.

Overall, the Anglo-Asante war of 1873-74 led to political instability that jeopardized economic activities, including kola production and marketing. Also, the 1873-74 crisis afforded an opportune occasion for the vassal states of the Asante kingdom to reassert their autonomy. This entailed political struggles for the control of the existing trade routes and markets, a subject that remains to be fully studied. Eventually, new markets emerged, including Kintampo, which was patronized by the Asantes. ${ }^{13}$

A spate of reports by a number of people who visited Salaga in the aftermath of the post-1873-74 crisis did stress the spatial dilapidation of Salaga. But more important, such eye-witness accounts consistently and unambiguously stated that the Salaga slave trade was still going on. ${ }^{14}$ David Asante, a pastor of the Basel mission, ${ }^{15}$ stated in 1877 that the population of Salaga was about 50,000 , and noted that "during Ashanti rule Salaga was the center of the slave trade, which is still flourishing." 16 Another account written by Asante and Theophil Opoku, 17 which subsequently appeared in the Proceedings of the Royal Geographical Society (London) in 1884, stated that "Phil Buss [a Basel missionary] found in 1878 that trade was at a 'standstill, excepting the slave trade." 18 Also, in correspondence to the Colonial Office in 1879 , Governor H.T. Ussher, emphasized the elasticity of the Salaga slave market. ${ }^{19}$

Thus, there is no doubt that by the mid-1880s, commercial activities in Salaga had returned to its former peak, but "instead of being the emporium at which the kola nut was the great attraction, the trade became more of a general character." 20 Asante concluded in 1884 that there had been a shift from Salaga as the main slave market to other markets, namely "Krakye, Kpando, Kpon[g] and Akra [Accra]."21 This in no way diminished the significance of Salaga as the main artery of slave supply to the Gold Coast. Indeed, Asante's mention of the southern markets of Kpando, Kpong, and Accra, suggests the expansion of slave-dealing and the increasing number of middlemen associated with the Salaga trading axis and who controlled the slave-transit markets in the Gold Coast. In 1889, the German L. Wolf reported that "Salaga is not the main market for kola nuts ... The slave trade is energetically carried on in Salaga, and correspondingly, doubtless, has the greatest interest there."22

While the sources of kola in the southern frontier regions of the Salaga trading axis suffered from the exigencies of the crisis of 1873-74, the sources of slaves to the north of Salaga remained intact and vibrant. Lovejoy and Johnson have provided information on the northern sources of the Salaga slave trade, including routes and destinations, population of traders and slaves, and marketing and price trends. ${ }^{23}$ The northern supply sources included Bornu, 
Yoruba (mid-Niger region), Timbuktu, and the Sokoto Caliphate, Mahdi [the Sudan], Djeddah, Bornu, and Wadai. ${ }^{24}$ Traders brought slaves and other commodities to the markets of the Salaga trading axis, where they purchased kola and European-made goods ${ }^{25}$ from Salaga-based middlemen and traders from the Gold Coast. Thus, the northern sources of slave supply to the Salaga market were enormous, affording regular supplies of not only slaves, but other commodities. It was this northern slave catchment area, presently identified as the "Nigerian" hinterland by Lovejoy, ${ }^{26}$ that continued to supply slaves and other commodities to the Salaga slave trading axis.

In addition to the slave supply sources in the "Nigerian" hinterland, four factors became crucial to the constancy of the Salaga slave trade to the postproclamation Gold Coast. First, Samori Turi's wars against African states and his resistance to French colonialism in the frontiers of the Salaga trading axis during the last quarter of the nineteenth century ${ }^{27}$ provided a conducive political climate for enslavement, dependency, and clientage. Second, the wars between Salaga and its neighbors and the Salaga civil wars of the 1890s had a double-pronged impact. For one thing, the struggle for power in the region provided the grounds for slave raiding, for example, Asante and Opoku wrote that the slave trade was briskly going on "owing to the [Salaga] war with the Mossi." 28 For another, the ensuing political disorder jeopardized preexisting economic ventures and hence prevented the use of slaves in agricultural production as had been the practice in the earlier decades. Consequently, such slaves had to be disposed of and the time-honored Gold Coast markets provided the venue. Third, a gun-slave cycle developed that made it easier for slaveraiders to acquire slaves. For instance, in 1888, von Francois wrote that the "Gasari people sell slaves and buy arms, [gun] powder and the best horses, to capture new slaves." 29 Lastly, a subject missing from the growing historiography of unfree labour forms in what is now modern Ghana, is how the burgeoning Gold Coast agrarian economy that developed after the 1873-74 crisis stimulated the Salaga slave trade. ${ }^{30}$ There is no doubt that the trade in oil-palm from the $1830 \mathrm{~s}$, followed by cocoa production in the last quarter of the nineteenth century, to a considerable extent, depended on slave labour obtained from the Salaga trading axis. ${ }^{31}$

For her part, Johnson's study offers a comprehensive overview of the relationship between the rulers of Salaga and the Gold Coast colonial government, and the impact of the Salaga slave trade on the Gold Coast. However, she does not offer an account of the patterns of the slave trade to the Gold Coast. Also she does not discuss the slave-supply networks between the Voltaic districts and the burgeoning agricultural regions to the west, namely the Akuapem-Krobo region and the Densu-Birim-Pra-Afram basin, and their implications for land tenure and social structure. Furthermore, Johnson overemphasizes the SalagaVoltaic connections and overlooks, indeed, what historians of the Gold 


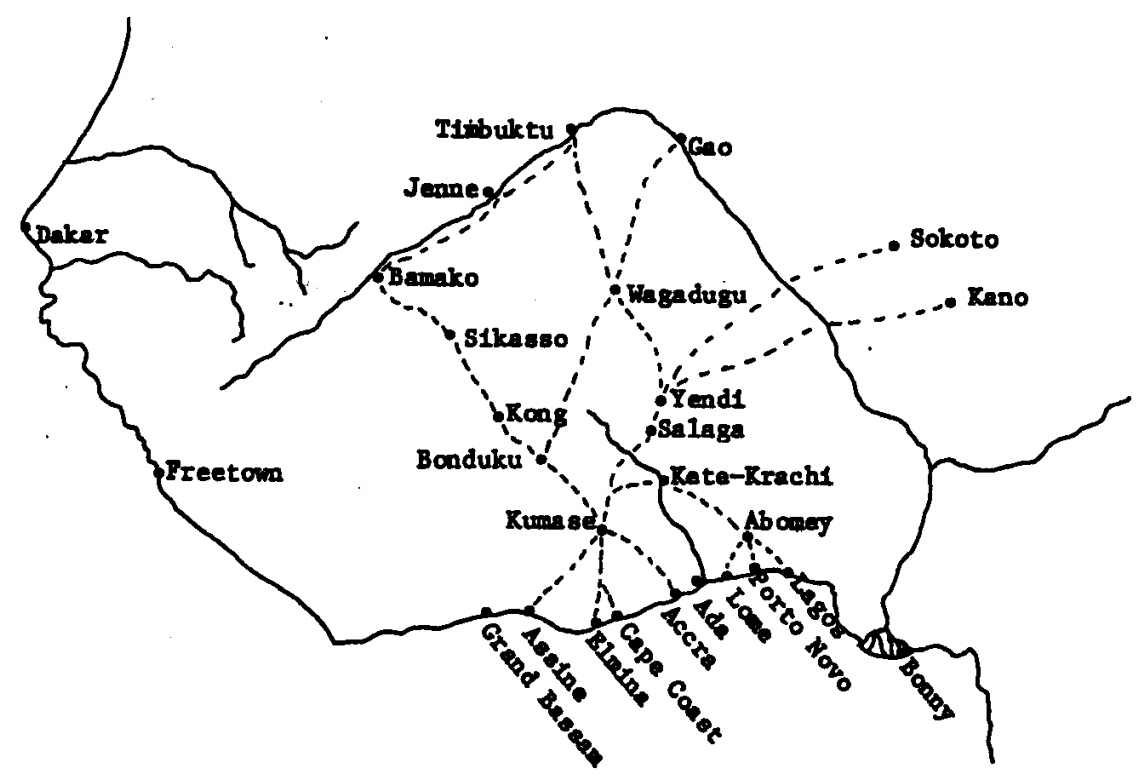

Figure 1: The Salags Market and Adjoining Teade Routes in West Africa in the $19+$ Century (Modified from from D. J. E. Maier, Priests and Power: Tbe Case of Denteb Sbrine in Ninetwentb-Cendury 


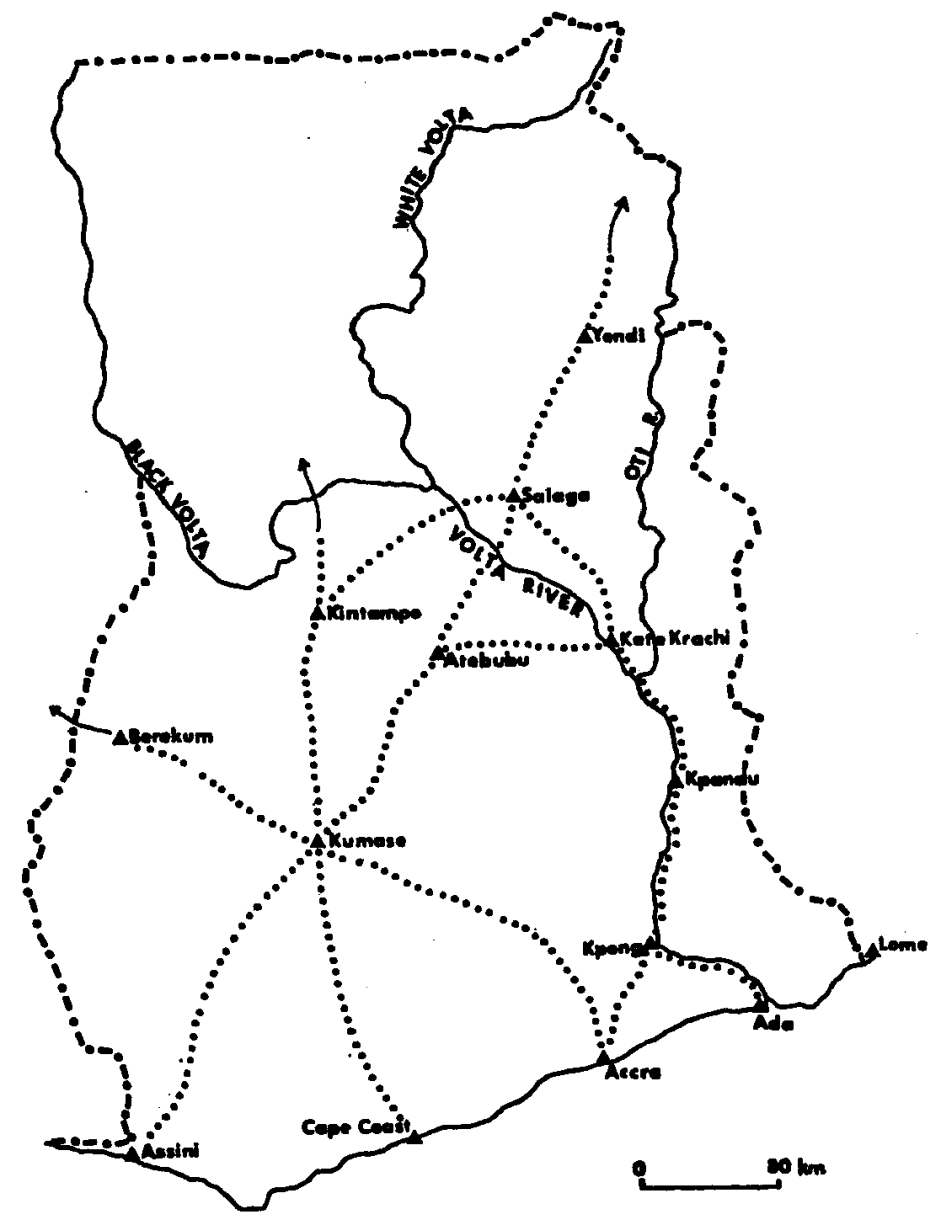

Figure 2: The Voltw Basin Trade Routes and Land Routes Linking Salage to the Coast (Modified from from D. J. E. Maier, Priarts and Power. The Case of Dorteb Strine in Nindeentb-Contury Gbava (Bloomington, 1983), 7. 
Coast in general have neglected: the significance of trade between the Salaga trading axis and the Gold Coast via the Praso-Manso trading corridor. ${ }^{32}$ Ironically, it is the Ghanaian playwright, Ama Ata Aidoo, who has captured the nature of economic activities, including slavery in the Praso-Manso trading corridor or what she aptly terms the "highway" in her play, Anowa. ${ }^{33}$

\section{DRAWING ATTENTION TO THE PERSISTENCE OF THE SALAGA SLAVE TRADE}

There are numerous accounts of the Salaga slave trade. They include reports written by colonial officers, European travellers, and Christian missionaries Africans and Europeans. ${ }^{34}$ However, the persistence of the Salaga slave trade to the post-proclamation Gold Coast was brought to the attention of the Colonial Office by two major reports. The first one was Inspector R.E. Firminger's report of 1887-89. Overly critical of the laxity in the colonial state's implementation of the abolition laws, Firminger revealed that child slavery, based on the Salaga trading axis, was prevalent outside the Protectorate, that is, the region between the Protectorate and Asante. ${ }^{35}$ Contrary to Firminger's conclusion, court records and the Basel Mission's reports on slave-dealing show that a considerable number of slaves from Salaga were bought both in the Protectorate and the Colony. ${ }^{36}$ Overall, child slavery based on the Salaga slave trading axis was common in the Gold Coast as a whole.

The second report was issued in August 1890 by H.R. Fox Bourne, the Secretary of the London-based Aborigines Protection Society (APS), in 188990. The report ${ }^{37}$ claimed that endemic child-slavery derived from the Salaga trading axis existed:

in the Colony and the adjacent British territories a great number of boys and girls, estimated at 5,000 or more, who are bought and retained as slaves, and that the practice of procuring these children from Salaga and other districts from the interior for sale at Accra and other places on the coast still continues and has of late been considerably increased. ${ }^{38}$

This disputes Firminger's conclusion and supports our viewpoint that postproclamation slave-dealing did occur in the Protectorate.

The colonial administration's response to Firminger and the APS' respective assertions exemplified the convoluted post-proclamation reports on slavery abolition that were meant to misinform the colonial office about the realities of abolition in the Gold Coast. ${ }^{39}$ Indeed, Governors Arnold Hodgson and Brandford Griffith cavalierly disputed the assertion of endemic post-proclamation slavery and the slave population estimates based on the Salaga slave trade. However, an exegetic reading of the two governors' respective flurries of reports, in addition to those of the district commissioners' amply support Firminger and the APS' claims of post-proclamation slavery. ${ }^{40}$ While the esti- 
mates of the servile population are disputable, the evidence strongly shows that those in servility were mainly children, especially prepubescent females, ${ }^{41}$ a phenomenon identified by several scholars. ${ }^{42}$

\section{COLONIAL CONCILIATORY POLICY TOWARDS SALAGA}

Johnson has explained that the British colonial policy of conciliation enabled the rulers of the Salaga trading axis to maintain their autonomy until the colonial occupation in 1897.43 In fact, successive colonial governments did not make any effort to intervene in the Salaga slave trade until the early twentieth century. The primary colonial objective between 1874-1899 was the ability of the rulers of the Salaga trading axis to maintain the security of the trade routes. ${ }^{44}$ For example, in 1882, Governor Samuel Rowe, writing to Lord Kimberley, the Colonial Secretary, noted that he had given the following instructions to the Lonsdale expedition to Salaga:

I have requested him [Captain Lonsdale] to make special point of visiting Crackey [Krakye] Dentey and of conciliating the authorities of that place. They are reported to still have more power than any of the other chiefs on the way to facilitate the free passage of travellers along the route from Salagha to Accra. ${ }^{45}$

While in Salaga, Lonsdale "went over the ground [he] had already traversed in reference to trade, trade routes, protection to [sic] traders... and conduct towards their neighbors" with chiefs and traders. ${ }^{46}$ To a large extent, the autonomy enjoyed by the Salaga rulers indirectly buttressed the ability of the slavedealers in the Salaga trading axis to supply slaves to the post-proclamation Gold Coast. ${ }^{47}$

In addition to Johnson's study, the duplicity of colonial officials in the slave trade is exemplified by independent reports. These include those by missionaries, traders, and non-British colonial authorities that mention slaves as an important commodity in the on-going trade. ${ }^{48} \mathrm{On}$ the contrary, colonial reports dealing with similar subject-matters and the same periods omitted slaves as an important item of trade. For example, a spate of detailed compilation of the volume of merchandise passing to and from Salaga and Cape Coast-Accra region via the Manso-Praso trading corridor, omitted slaves. ${ }^{49}$ Equally, detailed and voluminous reports on special colonial government-sponsored missions to Asante, Gonja, Dagomba, Brong, Buem, Nkonya, Peki, and Salaga only referred to slavery as a minor reference point, but not as an important aspect of such reports. ${ }^{50}$ Yet, it is patently clear from slave-dealing cases documented by the colonial courts and the Basel mission's accounts of the same period that a considerable number of slaves had been obtained from the Salaga trading axis. 51 
Closely linked with the conciliatory policy, and equally significant, was the colonial state's intent on recruiting slaves and former slaves into the colonial forces. Precedents of recruitment in the precolonial period encouraged the recruitment of slaves in Salaga during the post-proclamation period. For the precolonial period, Joseph Latorre's documentation of troops "recruited" in Kumase for the Dutch East Indies settlements between 1837 and 1842 shows that most of them came from the Salaga trading axis. ${ }^{52}$ In the $1850 \mathrm{~s}$, the Gold Coast Corps mostly comprised of slaves recruited in the Salaga trading axis. ${ }^{53}$ Johnson explains that in 1873, the British recruited runaway slaves in the Salaga area, and compensated their holders $£ 5$ per slave. ${ }^{54}$ In the same period, the British authorities had recruited slaves in the coastal areas to revamp the imperial forces. .55

Overall, leaders of various post-proclamation expeditions to the Salaga trading axis were advised not to interfere with matters of slavery there. ${ }^{56} \mathrm{In}$ 1879 , referring to the recruiting ventures in Salaga, Governor Ussher wrote that "it has become a matter of pressing necessity to raise their [Constabulary] numbers by any available means." 57 In 1881 , Governor Rowe assured the Lonsdale expedition:

but I trust that the reports which state that a considerable number of the persons who visit Salagha in connexion with [slave] trading caravans through that place are Houssas, and free to dispose of their labour in any way they like prove to be correct, and that many of these men will be found willing to accompany you [enlist]..$^{5}$

Governor Rowe was certainly not unaware of the fact that the caravans from the "Nigerian" Hinterland brought slaves to Salaga. He had prefaced his statement with "as the custom of slavery prevails in Salaga," advising that Captain Lonsdale should ignore slavery to avoid "antagonism with the authorities of the country." 59 Johnson has correctly surmised that "the Accra authorities can hardly have been unaware that recruits were being bought in Salaga." 60 Indeed, Wolf epitomized the fears of the British colonial authorities, when he wrote that: the whole importance of Salaga is so closely connected with it [the Slave trade] that the possible attempt of a European power to suppress it, could easily lead to a great war in which not only the Haussa but also the whole Western Sudan would take part. ${ }^{61}$

This may appear as an exaggeration, but there is no doubt that successive colonial administrators failed to raise the issue of slavery in Salaga for fear that it would jeopardize military recruitment in the region.

\section{THE SALAGA SLAVE TRADE TO THE CAPE COAST-ACCRA REGION}

We know much about the Salaga trading axis, but the nature of the trade and its regional interconnectedness in the post-proclamation Gold Coast remain to be 
fully understood. ${ }^{62}$ The Salaga-coastal trade may be conveniently divided into two zones: Salaga-Cape Coast-Accra ${ }^{63}$ and Salaga-Voltaic districts. ${ }^{64}$ The Cape Coast-Accra region linked the Salaga trading axis via the Manso-Praso trading corridor in the west. On the other hand, the eastern portion involved the Volta River and its tributaries, forming the arterial links between Salaga and the Voltaic districts. Goods were carried by slaves and pawns, but the SalagaVoltaic trade additionally involved the use of boats in the navigable parts of the Volta and its tributaries.

Overall, the Salaga-Cape Coast-Accra trade involved the states of Fanti, Denkyira, Asin, Akyem, Akuapem, Ga, Krobo, and Kwahu. It is probable that traders involved in the trade were from all these states, but the official records list only Kwahus, Gas, Fantis, and Akyems. Other traders were from Sierra Leone and Southern Nigeria; ${ }^{65}$ domiciled along the coast, they were generically described as "Hausa" and "Yoruba". ${ }^{66}$ As early as the 1870s, there were "Hausa" traders in Akyem; in fact, the "Hausa" trading diaspora in Akyem was still to be found there in the early twentieth century. ${ }^{67}$ Also, in 1890, Acting Governor Arnold Hodgson noted that there was a large Mohemmedan population in Accra, including Hausas, Mossis, and Grunsis, and that they had daily connection with the interior and the Salaga trading axis. ${ }^{68}$

In order to circumvent the colonial checkpoint on the Manso-Praso road, slave-traders from Salaga entered the Protectorate at other places, but returned to Salaga via the Manso-Praso route. ${ }^{69}$ They did so to avoid the possibility of being arrested for slave-dealing. ${ }^{70}$ This shows that the British were more concerned about slavery abolition in the Gold Coast than in the Salaga region. The Manso-Praso route was closely monitored because of the strong presence of the colonial government there. ${ }^{71}$ The main items of trade carried to Salaga by traders from the Gold Coast included salt, guns, gun powder, tin pans, and other European-made items. Returning to the Gold Coast from the Salaga trading axis, traders bought slaves, shea butter, ivory, goats, and sheep. ${ }^{72}$

As noted, the colonial sources are silent on the fact that slave trading was an integral aspect of the Salaga-Cape Coast-Accra trade. Fortunately, oral history collected by Professor John Fynn of the University of Ghana is informative. But the data has a problem of periodization: it is difficult to ascertain whether respondents were referring to the precolonial or colonial period. However, an extrapolation of the evidence based on respondents' references to the oil-palm trade points to a strong probability that they were referring to the "legitimate" trade in oil-palm products, specifically the period between 1830 and ca.1910. Conclusively, Fynn's data shows that a considerable number of slaves in the Fante region were obtained from the Salaga trading axis through the Manso-Praso trading corridor. ${ }^{73}$ Unlike the colonial sources, Fynn's data de-emphasizes European-made goods and stresses salt, kola, and dried fish as the main commodities carried by coastal traders to the Salaga region. The oral 
data affirms that coastal traders after exchanging or selling their wares in the Salaga markets, returned to the coast with slaves, gold, goats, and shea-butter, and that the trade routes from the coast to Salaga had "halting-places" or reststops. ${ }^{74}$ From the standpoint of Fynn's oral data, the pattern of precolonial trade in slaves between the Cape Coast-Accra region and the Salaga trading axis continued in the colonial period. ${ }^{75}$ In this regard, Lovejoy's transformation thesis is instructive: ${ }^{76}$ in the precolonial period Salaga served as a major source of slaves for the Atlantic slave trade, while in the colonial period, in fact, from the period of informal rule in the 1830 s, "slaves of Salaga" were increasingly put to local use in the Gold Coast.

\section{THE SALAGA SLAVE TRADE TO THE VOLTAIC DISTRICTS AND BEYOND}

Unlike the Salaga-Cape Coast-Accra trade, the Salaga-Voltaic trade offers a better opportunity for a detailed analysis. The commercial links between the Salaga trading axis and Voltaic districts are borne out by colonial reports, newspaper articles, and travellers' accounts. ${ }^{77}$ Despite the availability of sources, ${ }^{78}$ the coastal Voltaic districts, including Keta, Anloga, Kpong, and Ada, remain to be fully assessed. Scholars, who have studied both the precolonial and colonial political economies of the coastal Voltaic states have neglected to look at the impact of the Salaga trading axis upon the economies of the Voltaic coastal towns. ${ }^{79}$ Overall, very little is known about the mid-Voltaic districts, inhabited by the Pekis, Kpandos, Buems, and the Nkonyas. A satisfactory account of the mid-Voltaic districts needs to include Britain and Germany's respective lax colonial rule in the region; the series of inter-state wars that engulfed the districts; the role of the middlemen in the external slave trade; and the activities of Asante rulers and traders.

That the Salaga-Voltaic slave trade bore the imprint of continuity, similar to the Salaga-Accra-Cape Coast trade, is borne out by several eye-witness accounts. In 1862, a correspondent of the African Times, writing about the coastal Voltaic districts, noted that "now and then we see slaves gagged, or put in $\log$, passing to the slave coast." 80 A letter to the editor of the African Times in September 1863 submitted by someone in Keta is worth quoting at length:

People who formerly traded in palm oil now buy slaves, and every petty trader invests his little money in this more profitable trade. The slaves coming from the interior by the River Volta are sent down to Popo and Ahguay; and the people of the latter places also send money here to the traders to buy slaves for them..$^{81}$

Ten years later, on the eve of the imposition of colonial rule, another correspondent plaintively echoed:

At present it is thirty dollars and buyers complain. This is a great 
deal cheaper than what exists in the east ... tribes on this side of the coast who are not British subjects ... are privileged to buy what they call domestic slaves. ${ }^{82}$

In 1876, a letter to the editor of the African Times, captioned "Traffic in Slaves up the Volta; Salaga trade, \&c.," noted:

The Salaga trade is dull at this time; only some bags of salt are taken by the Addahs [Adas] to that part in exchange for slaves children of seven to nine years. They bring these [slaves] through the Volta to the Crobboes [Krobos] for exchanging palm oil. 83

Similarly, on March 15, 1884, Reverend F. Ramseyer, commenting on his journey to Salaga via the Volta River, reported that "the hunters here readily dispose of their store of ivory to a caravan from Salaga, which was travelling coastward with slaves, sheep, and cloth." 84

That the slave trade in the coastal Voltaic districts continued was due to a number of factors. The British abandonment of the fort at Keta in 1862 brought to an end the naval patrols that had suppressed slave trading in the region. 85 This stimulated the external slave trade to other parts of Africa and perhaps to the Americas from the mid-1860s to about mid-1880s. During this period, Geraldo de Lima, for example, actively engaged in the slave trade to Abosome, Lome, and the islands off the coast of West Africa. ${ }^{86}$ The situation was worsened by the fact that in the neighboring regions to the west, that is the Eastern Province, the colonial state was suffering from the paucity of officials. The inadequate number of personnel led to an inept abolition policy. Overall, it provided fertile grounds for predatory activities and slave-dealing in the regional backwater between the Salaga trading axis and the Gold Coast, especially the northern frontiers of the coastal Voltaic districts. ${ }^{87} \mathrm{~A}$ classic case was that of de Lima, who from the late $1860 \mathrm{~s}^{88}$ pitched the Anlos against the Adas, and was only subdued by a series of colonial military expeditions in the 1880 s. Not only did de Lima engage in the internal slave trade, but he also used his slaves to facilitate smuggling in the region. ${ }^{89}$

Overall, the problem of slave-dealing and predatory ventures were exacerbated by the exigencies of the Asante-Anglo war of 1869; the anarchy it unleashed in the region ${ }^{90}$ made it difficult to suppress the slave trade. ${ }^{91}$ In 1873, for example, a correspondent of the African Times, wrote:

I need not say anything about domestic slavery, which is being carried on here in its perfection. Since the late war [Anlo-Asante war of 1869] the price of a boy or a girl of twelve years old has been $£ 2.15 \mathrm{~s} .{ }^{92}$

In 1880, Governor Ussher expressed concern about the predatory activities of "Hausa raiders" on the frontiers of the Volta and concluded that "This is a serious matter, as it is most desirable that the great road through Salaga into the heart of Central Africa [Sudan] should be rendered safe." 93

That slave-dealing was thriving in the coastal Voltaic districts was also due 
to the fact that unlike the Cape Coast-Accra trading emporium, the former lacked the intermittent colonial vigilance that mitigated slave-dealing in the latter. The coastal Voltaic districts remained under lax colonial control well into the late $1880 \mathrm{~s},{ }^{94}$ exacerbated by the multifaceted problems of paucity, high mortality rate, ${ }^{95}$ and inexperience of European officers. ${ }^{96}$ Thus, throughout the last quarter of the nineteenth century, these problems undermined the effectiveness of abolition in the region.

With regard to the mid-Voltaic districts, the colonial presence of Germany and Britain, straddling the Volta river, remained ineffectual until about 1900. As a result, slavery thrived in the region. In 1895, Muller writing about the prevalence of slavery and pawning ${ }^{97}$ in Anum and Buem noted that:

once the laws of slavery were vigorously pursued by the [German colonial regime], but for the last ten years the colonial officials have left the people in peace and administered the slavery law in a very superficial way. ${ }^{98}$

Another Basel missionary, Clerk, also reported in 1891 that in "'German' Kpando," for example, "the slave trade has revived." 99 Again, in 1896, Clerk reported that:

many slaves have fled in the course of the year, and a few been [sic] recaptured. No German official has raised the subject of slavery in Buem, and buying and selling continues unabated. 100

The Basel Mission blamed German anti-slavery policy for the slave trade in the mid-Voltaic districts. Muller, for example, had lamented that "the people thought that German regulations over slavery were simply directed to seeing that the slaves were not badly handled." 101 As a result of the lax abolition policy, slave traders had a field day practicing their dubious craft.

The slave-trading transit markets in the west-central Voltaic districts of Nkoranza, Krakye, and Atebubu, all with direct commercial intercourse with Salaga and the "Nigerian" hinterland, were not different. As late as 1896, Basel missionaries who visited Krakye, Nkoranza and Atebubu recounted the increasing slave-trading ventures in the district. ${ }^{102}$ Peregaux, for example, stressed that "slaves are commonly bought and sold - price for a man $£ 8$, a woman $£ 8-9$, and child $£ 5-6 . " 103$ Also, in 1897, Muller reported that Clerk and Martin had agreed with Ramsyer's report that:

slave dealing had moved from Kintampo to Krakye ... and it was a fact that slave dealing goes on in Kete [Krakye], not so much in the market as in the houses. Over the whole area, buying and selling goes on unchecked. ${ }^{104}$

In addition, the Salaga-Voltaic slave trade persisted due to the continuity 105 in the supply of commodities, such as guns, gun-powder, salt, and liquor schnapps - which were in high demand. ${ }^{106}$ In 1896, Martin, a Basel missionary, was informed in Kpando that one "cannot buy a slave except with spirits or [gun]-powder."107 Also, the Adas transported salt to Salaga and 
"exchang[ed]" it for slaves, and returned to the coast, where they "exchang[ed] the slaves for palm oil" in Krobo. ${ }^{108}$ In fact, the commodities of the trade explain the participation of the Asantes in the slave trade in the Voltaic districts. The trade provided the Asantes with an opportunity to acquire firearms at a time when trading opportunities with their Elmina allies in the Manso-Praso corridor had declined. ${ }^{109}$ It should be stressed that during the last quarter of the nineteenth century, Asante rulers needed arms to suppress the tide of secessionist movements, for example, the one orchestrated by the Dwaben state. More importantly, the looming shadow of British colonial rule in Asante, following the Asantes' nominal defeat in the Anglo-Asante war of 1873-74, called for a state of war readiness that increasingly depended on the Asantes' ability to obtain weapons of war. Overall, all these factors firmly anchored the slave trade in the Salaga-Voltaic districts. Despite the plaintive reports of the APS and the Anti-Slavery Society, during the 1880 s and 1890 s, the slave trading conduits between the Salaga-Voltaic emporium of trade and the Gold Coast remained active and vibrant. ${ }^{110}$

Johnson's study does not make clear the linkages between the Voltaic ports and the Dahomian ones. ${ }^{111}$ The Voltaic ports, namely Keta, Ada, and Kpong linked the Dahomian ports of Abosome, Whyda and Porto Novo. ${ }^{112}$ This interconnectedness enabled slaves and "wage labourers" to be ferried to other parts of Africa, such as Loanda, Fernando Po, St Thomas and the Princes. ${ }^{113}$ Undoubtedly, the evanescent colonial anti-slavery measures compelled slavetraders to disguise slaves as migrant wage labourers. Thus, the evidence strongly shows that slave exports persisted alongside migrant wage labour well into the 1880 s.

The slave trade along the Voltaic coastal ports was coterminous with the Salaga-Cape Coast-Accra region: the former supplied the demand for servile labour in the Densu-Pra-Birim-Afram agricultural basin. 114 This explains why descendants of "Northerners" from the Salaga trading axis and Anlo-Ewes enslaved by the Akans and Ga-Adangbes still inhabit the agricultural areas of the Afram plains and the Densu-Pra-Birim basin. ${ }^{115}$ Indeed, Edward Reynolds, writing on Akuapem, has revealed that:

Even today Ewes [from the Voltaic districts] and Northerners

[Salaga slave trading axis] whose countrymen provided the slave labour for the oil palm plantations, continue to do much of the work involved with oil palm plantations. 116

The above has some implications for the social structure: descendants of slaves and to a smaller extent migrant wage labourers in the cocoa farming communities and trading towns in south-eastern Ghana, for example, in the Akuapem and Birim-Densu-Pra and Afram basin, are said to have been "assimilated" into host-kinship groups. The "assimilation" is borne out by the fact that descendants of slaves have usufructuary rights in land, bear the names of the 
host-kinship groups, and speak the language of their hosts. However, their "outsider" status is exemplified by their lack of access to inheritance and political office within host-kinship groups. ${ }^{117}$

\section{SOCIAL FEATURES AND LEGAL NUANCES OF POST-PROCLAMATION SLAVERY}

Despite the spate of studies of post-proclamation slavery in the Gold Coast, excepting Robertson's case study of post-proclamation female slavery in Accra, we know very little about the institutional peculiarities of post-proclamation slavery. Much of the literature has devolved on the responses of slaves, processes of freed slaves' independent adjustment to freedom, the role of the colonial state and the Christian missions in the adjustment of freed slaves, and the responses of slave-holders. ${ }^{118}$ As noted, this section complements Robertson's case study of post-proclamation female slavery in Accra. It offers further insights into post-proclamation slavery and legal nuances of the administration of the abolition laws.

The district commissioners' responses to Firminger's report of 1889-1890, is revealing for the historiography. ${ }^{119}$ Varying in explanatory and statistical detail, the district commissioners' reports, as noted, supported Firminger and the APS' respective assertions of endemic post-proclamation slavery. The statistical table provided by Mr. E. MacMunn, the district commissioner of Accra, is the most informative and affords an opportunity for a case study. In all, he submitted two reports. In the first one, he noted:

From information 120 I received, which I actively pursued, I was fortunate enough in catching offenders in Accra and the neighbouring villages, say in a distance of 25 to 35 miles, and in a space of two weeks had in my possession eleven slave children (four boys and seven girls from about 13 years to five years). 121

This strongly affirms our conclusion that the transit markets for slave-trading were in the Protectorate and its immediate environs. Given the paucity, inexperience, and high mortality rate of European officers, abolition in the Colony was more effective than in the Protectorate. Simply, the colonial presence in the Colony was stronger than in the Protectorate, hence hindered slave trading in the former.

Macmunn's second report shows that between 26 July, 1889 and 21 October, 1889, there were 10 slave-dealing cases. These cases involved 11 slave-dealers and 14 slaves consisting of 10 girls and 4 boys who ranged between 4 to 14 years old with the average age at 7.5 years. Out of the 14 slaves, 8 were brought from Salaga and one from a "Grunshie village" - by all accounts, located in the Salaga trading axis - and 5 were bought from middlemen in the Ga region, suggesting that the 5 slaves may have been brought from 
the Salaga trading axis. ${ }^{122}$ The data also shows that middlemen operated both in the Colony and the Protectorate, affirming our disputation of Firminger's conclusion that slavery was only endemic outside the Protectorate.

If we hazard the use of indigenous African names as a unit of analysis, the evidence suggests that 4 of the 11 slave-dealers were presumably of "Hausa" extraction, 2 were likely Akans, and 5 were probably Ga-Adangbes. ${ }^{123}$ This supports the viewpoint that some of the "Hausas" in the Colony were middlemen. Also, out of the 8 slaves brought from Salaga, 6 had been given Akan names and 2 had Ga-Adangbe names. ${ }^{124}$ Additionally, 2 of the slaves with GaAdangbe names were bought from "some Hausa people." 125 Furthermore, the origin of 4 of them were not indicated, but 4 had Ga-Adangbe names. ${ }^{126}$ The change of name was a common practice, a ploy indicating that slaves were members of host-kinship groups that bore specific names. This practice sought to prevent colonial officials from ascertaining the foreign origin of slaves, with its consequent manumission and prosecution of slave-dealers. ${ }^{127}$ Paradoxically, this was in a Ga region and one would have expected that most of the 8 slaves brought from the Salaga trading axis would bear Ga names. Rather, 6 of them bore Akan names, strongly confirming that the Protectorate and its immediate environs, primarily Akan-based, served as the transit slave-marketing center for the Colony. 128

The slave price indices in the Gold Coast mirrored the prevailing price trends in the Salaga slave trading axis: girls commanded higher prices than boys because there was a higher demand for the former than the latter. Out of the 14 slave-dealing cases, purchasing prices were given for 7 of them: 4 girls and 3 boys. The purchasing prices of the girls ranged from $£ 33 \mathrm{~s}$. $6 \mathrm{~d}$. for 6 to 7 -year olds to $£ 8$ for those older, while those for boys ranged from $£ 210 \mathrm{~s}$. $6 \mathrm{~d}$. for 6-year olds to $f 6$ for $9-10$ year olds. ${ }^{129}$ Overall, gender and age of the "slaves of Salaga" corresponded to the servile population demographics in the Gold Coast. The various accounts of the Salaga trading axis stress the preference for mostly young people, boys and girls, and people of middle age. ${ }^{130}$ Correspondingly, the reports submitted by Firminger, district commissioners, and the APS, all affirm the predominance of child slaves in the Gold Coast, with a higher preference for prepubescent girls. ${ }^{131}$

Another interesting feature is the nature and terms of incarceration of slave-dealers. MacMunn's second report provides an insight into the arrest and conviction of slave-dealers. According to MacMunn, the period of arrest and conviction occurred between 26 July, 1889 and 21 October, 1889. The base term of imprisonment was a minimum of 3 months with hard labour. Fines with or without hard labour ranged from $£ 2$ to $£ 25.132$ The court rulings suggest that non-"Hausa" slave-dealers, mainly elites of the colonial society, paid fines that were smaller than the purchase prices at which they had bought slaves. 
Conversely, "Hausa" slave-dealers paid fines that were higher than the purchase prices. ${ }^{133}$ These differing fines suggest that the courts treated the cases of the so-called "Hausa" slave dealers more harshly than those considered non"Hausa", signifying the fact that notables 134 in the Colony influenced the outcomes of court cases involving slave children. The case of Fanny Hagan of Accra, is illustrative. On March 26, 1890, she was tried by MacMunn and fined $£ 3$ for having bought Nyamie Domah, a slave girl. MacMunn placed Nyamie Domah under the custodial care of a prison matron to be "apprenticed according to law." However, "almost immediately afterwards ... [MacMunn] was peremptorily ordered by [Governor] Sir W. Brandford Griffith to restore the child to the convicted slave holder - Fanny Hagan." 135 By all accounts, Fanny Hagan was an influential society lady, who had her way about with colonial officials, and her case was not the only one. For instance, Ellen Quartey, "the concubine of a white resident" had her slave-dealing charges quashed. ${ }^{136}$

\section{CONCLUSION}

This study has complemented the respective studies of Lovejoy and Johnson. It has examined the Salaga slave trading axis, placing emphasis on its contribution to the supply of slaves to the post-proclamation Gold Coast. I have argued that the crisis of 1873-74 was ephemeral and did not affect the northern supply sources of slaves to Salaga. As a result, the Salaga trading axis remained an important component of the slave trade in the post-proclamation Gold Coast. Future studies may reveal the complexities of the slave trade to the Gold Coast, including its capital underpinnings, a detailed account of the trade routes, and most importantly, the impact of the Salaga slave trade on enslavement in the post-proclamation Gold Coast, a subject that remains to be fully understood.

Among other things, I have suggested that the slave trade in the SalagaVoltaic region, a more anarchic region, though lacking actual figures, supplied more slaves than the Salaga-Accra-Cape Coast zone, which in comparative terms, was better monitored by the British colonial government. The Asantes participated in the Voltaic trade not only as middlemen, but more importantly, the trade allowed them to acquire guns and gun-powder. Additionally, the study shows that the external slave trade from the Voltaic districts to other parts of Africa, and perhaps to the Americas, continued well beyond the $1860 \mathrm{~s}$. I have argued that given the evanescent nature of antislavery policies in the region of the Voltaic ports, it is probable that slaves exported to other parts of Africa were disguised as migrant labourers. Furthermore, the post-proclamation Salaga slave trade to the Gold Coast impacted the social structure of the areas where such slaves were used, for example, in the Pra-Birim-Densu agricultural basin. The features of the post-proclamation slave trade affirm conclusions of earlier studies that prepubescent female slaves predominated in the trade. Lastly, the 
legal nuances that underscored post-proclamation slavery shows the ineptitude of colonial officials and inconsistencies in the application of the abolition laws.

1 This viewpoint is espoused by most of the authors in Susan Miers and Martin Klein, eds., Slavery and Colonial Rule in Africa (London, 1999); for the summary, see Suzanne Miers and Martin Klein, "Introduction," 47.

2 Broadly, the Gold Coast covered the area between Asante and the Atlantic Ocean. It was divided into two administrative and geographical spheres: the colony and the protectorate. The colony was the coastal enclave that had had contact with the Europeans from the fifteenth century. The protectorate, the interior region between the coastal belt and Asante, was first brought under European rule in the late nineteenth century. Until 1901 the boundaries between the colony and the protectorate remained nebulously defined. See, for example, Francis Agbodeka, African Politics and British Policy in the Gold Coast 1868-1900 (London, 1971), 55-61.

${ }^{3}$ See, for example, Paul E. Lovejoy, "Polanyi's 'Ports of Trade': Salaga and Kano in the Nineteenth Century" in Canadian Journal of African Studies, 16 (1982), 245-277; and Marion Johnson, "Slaves of Salaga" in Journal of African History, 27 (1986), 341-362.

4 Ibid.

${ }^{5}$ For the processes of abolition of unfree labour in the Gold Coast, see for example, Raymond Dumett, "Pressure Groups, Bureaucracy, and the Decision-Making Process: the Case of Slavery Abolition and Colonial Expansion in the Gold Coast, 1874" in Journal of Imperial and Commonwealth History, 9 (1981), 193-216; Gerald M. McSheffrey, "Slavery, Indentured Servitude, Legitimate Trade and the Impact of Abolition in the Gold Coast, 1874-1901" in Journal of African History, 24 (1983), 349-268; Claire C. Robertson, "Post-Proclamation Slavery in Accra: A Female Affair" in Klein and Robertson, Women and Slavery in Africa (Madison, 1983), 220-245; Raymond Dumett and Marion Johnson, "Britain and the Suppression of Slavery in the Gold Coast Colony, Ashanti and the Northern Territories" in Suzanne Miers and Richard Roberts, eds., The End of Slavery in Africa (Madison, 1988), 71-116; Kwabena OpareAkurang [Akurang-Parry], "The Administration of the Abolition Laws, African Responses, and Post-Proclamation Slavery in Colonial Southern Ghana, 1874-1940" in Slavery and Abolition, 19 (1998), 149-166. Kwabena O. Akurang-Parry, "Slavery and Abolition in the Gold Coast: Colonial Modes of Emancipation and African Initiatives" in Ghana Studies, 1 (1998), 11-34; Kwabena O. Akurang-Parry, "A Smattering of Education' and Petitions as a Source Material: A Study of African Slave- 
Holders' Responses to Abolition in the Gold Coast, 1874-75" in History in Africa, 27, (2000), 39-60; Kwabena O. Akurang-Parry, "“With a Load on His Head and Nothing in His Hands:' The Opposition of the Gold Coast (Ghana) Press to the Compulsory Labor Ordinance" in Transactions of the Historical Society of Ghana, forthcoming; Kwabena O. Akurang-Parry, "Colonial Forced Strategies for Road-Building in the Gold Coast (Southern Ghana) and International Anti-Forced Labor Pressures, 19001940" in African Economic History, forthcoming; Kwabena O. AkurangParry, "What is and What is not the Law:' Imprisonment for Debt and the Institution of Pawnship in the Gold Coast, 1821-1899" in Paul Lovejoy and Toyin Falola, eds., Pawnship, Slavery and Colonialism in Africa (New Brunswick, NJ, 2001), in press; and Peter Haenger, Slave and Slave Holders on the Gold Coast (Basel, 2000).

6 Johnson, "Slaves of Salaga."

7 For an account of these marketing centers, see, for example, Kwame Arhin, "Transit Markets in the Asante Hinterland in the Nineteenth Century" in Odu: A Journal of West African Studies, 9 (1974), 5-22.

8 See, for example, J.K Fynn, Oral Traditions of the Fante States No. 5 Abeadzie (Legon, 1974); and J.K Fynn, Oral Traditions of the Fante States No. 6 Eyanmaim, Eyan Denkyera, and Eyan Abaaasa (Legon, 1975); and Kwame Y. Daaku, "Trade and Trading Patterns of the Akan in the Seventeenth and Eighteenth Centuries" in Claude Meillassoux, ed., The Development of Indigenous Trade and Markets in West Africa (London, 1971), 168-171.

9 See the work of synthesis by Raymond E. Dumett, "Traditional Slavery in the Akan Region in the Nineteenth Century: Sources, Issues, and Interpretations," in David Henige and T.C. McCaskie, eds., West African Economic and Social History: Studies in Memory of Marion Johnson (Madison, 1990), 8; Mary McCarthy, Social Change and the Growth of British Power in the Gold Coast (Lanham, 1983), 130-131; and Johnson, "Slaves of Salaga."

10 See, for example, Sandra E. Greene, Gender, Ethnicity and Social Change on the Upper Slave Coast (Portsmouth, NH., 1996), 128; Sandra E. Greene, "The Individual as Stranger in Nineteenth-Century Anlo: The Politics of Identity in Precolonial West Africa" in John Hunwick and Nancy Lawler, eds., The Cloth of Many Colored Silks (Evanston, 1996), 109; and Sandra E. Greene, "Cultural Zones in the Era of the Slave Trade: Exploring the Yoruba Connection with the Anlo-Ewe," in Paul Lovejoy, ed., Identity in the Shadow of Slavery (London, 2000), 96. In this most recent study, Greene seems to have revised her end-date of the external slave trade from the early 1860 s to the late $1860 \mathrm{~s}$.

11 Robertson, "Post-Proclamation Slavery," 220-245. 
12 Lovejoy, "Polanyi's "Ports of Trade," 257. For the kola trade, see Paul E. Lovejoy, Caravans of Kola, The Hausa Kola Trade: $1700-1900$ (Zaria, 1980).

13 Marion Johnson, Salaga Papers, Vol. I (Legon, 1965), SAL/16/1; and SAL $18 / 1$.

14 See, for example, Johnson, Salaga Papers, Vol. I, SAL/3/1; SAL/54/1; $\mathrm{SAL} / 18 / 1$; and SAL/12/1.

15 See, for example, Haenger, Slave and Slave Holders, 17, which shows that David Asante was the first African trained as a missionary in Basel. Later on a serious conflict developed between Asante and the Akyem Abuakwa rulers. See 132-140.

16 Johnson, Salaga Papers, Vol. I SAL/3/1; SAL/54/1; and SAL/67/1.

17 For an account on Theophil Opoku, see Haenger, Slave and Slave Holders, 156.

18 Johnson, Salaga Papers, Vol. I, SAL/4/1.

19 Ibid., SAL/54/1.

20 Ibid., SAL/16/1. In fact, the Lonsdale mission to Salaga in 1882 reveals that by the early 1880 s "small quantities" of kola from Akyem were "disposed of at once [in Salaga] without difficulty." See Rowe to Kimberley, May 10, 1882, Encl. 2 in No. 42 in Further Correspondence Regarding Affairs of the Gold Coast, Parliamentary Papers, 1882, C. 3386 (hereafter C. 3386).

21 Johnson, Salaga Papers, Vol. I, SAL/5/1.

22 Ibid., SAL/12/1.

23 Lovejoy, "Polanyi's 'Ports of Trade," 251-257; and Johnson, "Slaves of Salaga," 346-349.

24 See Johnson, Salaga Papers, Vol. I, SAL/3/1; SAL/12/1; and Johnson, "Slaves of Salaga," 346-349. See also C. 3386, Rowe to Kimberley, 10 May, 1882, Encl. 2 in No. 42.

25 For some of the commodities of the trade, see $C, 3386$, Rowe to Kimberley, 16 January, 1882, No. 18. The non-slave commodities of the trade included cattle, sheep, goats, mules, poultry, beef, mutton, milk, butter, Asante kola; yams, guinea corn, maize, spices, salt, honey, black European potatoes, Tagyan ivory, country cloth; incense, Gyaman cotton, soap, Hausa woolens, carpets, silks,

leather wares, ostrich feathers, sandals, slippers, colored bark mats, weapons, mirrors, needles, arms, brass rods, lavender, mirrors, sugar, and scissors. See also, Johnson, Salaga Papers, Vol. I, SAL/76/2; SAL/21/2; $\mathrm{SAL} / 3 / 1 ; \mathrm{SAL} / 4 / 1$; and SAL/12/1. There were two major markets in Salaga. The morning market was devoted to the selling of food and perishable items. The afternoon market, which was more important than the morning market, was devoted to the selling of foreign commodities, 
including "North African, Egyptian, Arabic and even European" ones. See Johnson, Salaga Papers, Vol. 1, SAL/3/1. While there was barter, monies included cowries, silver coins, Prussian thaler, and English quarter and shillings. See Johnson, Salaga Papers, Vol. 1, SAL/3/2; SAL/12/1; $\mathrm{SAL} / 57 / 1$. Silver coins, apart from being a medium of exchange were prized in the interior because they were converted to amulets, rings, and bracelets.

${ }^{26}$ The "Nigerian" hinterland includes what is now Nigeria, Benin, parts of modern Ghana, Cameroon, Niger, and Chad. For a fuller account, see Paul E. Lovejoy, "Biography as a Source Material: Towards a Biographical Archive of Enslaved Africans," in Robin Law, ed., Source Material for Studying the Slave Trade and the African Diaspora, Occasional Paper No. 5 (Stirling, 1997).

27 See, for example, A. A. Iliasu, "The Establishment of British Administration in Mamprugu, 1898 - 1937" in Transactions of the Historical Society of Ghana 16 (1975), 1; and Patrick Manning, Slavery and African Life (Cambridge, 1990), 140 and 159.

28 Johnson, Salaga Papers, Vol. I SAL/4/1.

29 Ibid., SAL/18/I.

${ }^{30}$ See, for example, Beverly Grier, "Pawns, Porters, and Petty Traders: Women in the Transition to Cash Crop Agriculture in Colonial Ghana" in Toyin Falola and Paul E. Lovejoy, eds., Pawnship in Africa (Boulder, 1994), 161-186.

${ }^{31}$ See, for example, J. K. Fynn, Oral Traditions of the Fante States No. 1 Abrem (Legon, 1974), 10-13; and Fynn, Oral Traditions of the Fante States No. 5 Abeadzie, 13-14.

32 For a geographical account of this route, see C. 3386, Rowe to Kimberley, 17 October, 1881, Encl. 7 in No. 7; Encl. 9 in No. 7; Encl. 10 in No. 7; Encl. 11 in No. 7; and Encl. 12 in No. 7.

${ }^{33}$ Ama Atta Aidoo, Anowa (London, 1970), 22-42. Trading ventures along the highway forms the source of the antagonist, Kofi Ako's wealth based on trade in animal skins. As he expands his trading ventures, he turns to slavery to buttress his wealth. This sharpens the heroine, Anowa's consciousness about social inequalities and class differences, accentuating her earlier rebelliousness against conventional norms of gender inequality. Consequently, the import of Anowa is not its radicalism as a feminist discourse or a female radicalization of a male-dominant utopia. Rather, its thematic relevance lies in the contradiction in wealth in slaves or materiality and the human tragedy of the Fanteland in the nineteenth century.

34 These include Johnson, Salaga Papers, Vols I; Paul Jenkins, Abstracts of Basel Mission Gold Coast Correspondence (Legon, 1970), (hereafter Jenkins, $B M C$ ); ADM series, SCT series, Annual Reports, Departmental 
Reports of the National Archives of Ghana (hereafter NAGA); British and Gold Coast newspapers; and British Parliamentary Papers. See, also the notes in Johnson, "Slaves of Salaga."

${ }^{35}$ See Correspondence Respecting the Slave Trade, Parliamentary Papers, 1889, C. 6010 (hereafter 6010); Correspondence Respecting the Slave Trade, Parliamentary Papers, 1890, C. 6053 (hereafter 6053); and Correspondence Respecting the Slave Trade, Parliamentary Papers, 1890, C. 6199 (hereafter 6199). Firminger himself was alleged to have purchased a Foulah [Fulani] slave girl named Fatima from a Mama Dankwana Wurri, a Mossi slave dealer, for £6: 10., when he visited Salaga in 1887. See Johnson, Salaga Papers, Vol. I SAL/72/1; and SAL/73/1.

36 See, for example, Haengar, Slave and Slave Holders, 156-157.

37 For a fuller discussion of the report and other correspondence, see Correspondence Respecting the Administration of the Laws Against Slavery in the Gold Coast Colony, Parliamentary Papers, 1891, C. 6354 (hereafter 6354).

38 C. 6354 , The APS to Colonial Office, 20 August, 1890, No. 1; and The Times (London), 1 September, 1890.

39 See, for example, McSheffrey, "Slavery," 350-351.

${ }^{40}$ See their reports in C. 6010; C. 6053; and C. 6354.

41 See, for example, C. 6053, MacMunn to Hughes, 5 November, 1889, Encl. 3 in No. 59; C. 6053, Cole to Hughes, 5 September, 1889, Encl. 8 in No. 59; C. 6053 , Holmes to Hughes, 27 July, 1889, Encl. 26 in No. 59; and C. 6053, Statement of Mr. J. A. Smith, Encl. 34 in No. 59.

42 Robertson, "Post-Proclamation Slavery," 220-245; Gareth Austin, "Human Pawning in Asante, 1800-1950: Markets and Coercion, Gender and Cocoa," in Falola and Lovejoy, eds., Pawnship in Africa, 119-159; Grier, "Pawns," 161-186; Akurang-Parry, "Missy Queen," chapter 8; and Kwabena O. Akurang-Parry, “'The Loads are Heavier than Usual:' Forced Labor by Women and Children in the Central Province, Gold Coast (Colonial Ghana), ca. 1900-19-40" in African Economic History, forthcoming.

43 Johnson, "Slaves of Salaga," 358-361.

44 Gold Coast Despatches from Governor to Secretary of State, 1876-77, 28 March, 1877, No. 87, NAGA, ADM 1/1/21; Gold Coast Despatches from Secretary of State to Governor, 1877, 9 March, 1877, No. 408, NAGA, ADM 1/1/43; C. 3386, Rowe to Kimberley, 17 October, 1881, No. 7; C. 3386, Rowe to Kimberley, 17 October, 1881, Encl. in No 7; Johnson, Salaga Papers, Vol. 1, SAL/37/1; Gold Coast Despatches from Governor to Secretary of State, 1882, 9 August, 1882, No. 366, NAGA, ADM 1/2/27; Gold Coast Despatches from Secretary of State to Governor, 19 December, 1883-26 May, 1884, 19 December, 1883, Encl. in No. 441; and The 
London Chamber of Commerce to Colonial Office, 22 April, 1886, No. 6 in Further Correspondence Respecting the Affairs of the Gold Coast, Parliamentary Papers, 1886, C. 4906 (hereafter 4906).

45 Johnson, Salaga Papers, Vol. I SAL/37/1.

46 C. 3386, Rowe to Kimberley, 10 May, 1882, Encl. 2 in No. 42.

47 See, for example, NAGA, SCT 17/5/6; and Gold Coast Despatches from Secretary of State to Governor, 1880 Pt. 2, 27 October, 1880, No. 147, NAGA, ADM 1/1/51.

${ }^{48}$ See, for example, the accounts in Johnson, "Slaves of Salaga," 349-355; and Johnson, Salaga Papers, Vol 1.

${ }^{49}$ For some of the commodities of the trade, see note 25. The Manso-Praso route was the main trading corridor that linked the coastal markets with the interior ones, including the Salaga trading axis.

${ }^{50}$ See, for example, C. 3386, Rowe to Kimberley, 10 May, 1882, Encl. 1 and 2 in No. 42; and Johnson, Salaga Papers, SAL/76/1 1876.

${ }^{51}$ See, for example, NAGA, SCT 17/5/6, Criminal Record Book, October 1886 -June 1888; NAGA SCT 17/5/9, Criminal Record Book, October 1889-August 1890; and NAGA, SCT 17/5/12, Criminal Record Book, 23 September, 1891.

52 Joseph R. LaTorre, "Birthplaces of Dutch East Indies Troops "Recruited" in Kumase, 1837-1842," The Asante Collective Biography Project Bulletin, 5 (1976), 31-42.

${ }^{53}$ McCarthy, Social Change, 123 and 131-132. The Gold Coast Corps was formed after 1850 when the Gold Coast administration was separated from Sierra Leone, consequently leading to the withdrawal of the West Indian Regiment from the Gold Coast. With the formation of the Gold Coast Corps and the announcement of benefits, including lodging, medical care and wages, the odonkos left their holders to join the Gold Coast Corps. See 159.

54 Johnson, "Slaves of Salaga," 355-356.

${ }^{55}$ See, for example, The Anti-Slavery Reporter (London), 1 January, 1874, 10.

56 See, for example, Johnson, The Salaga Papers, Vol. I, SAL/59/1; and SAL $/ 37 / 1$.

${ }^{57}$ Gold Coast Despatches from Governor to Secretary of State, 1879-80, 18 July, 1879, No. 167, NAGA, ADM 1/2/23. See also Gold Coast Despatches from Secretary of State to Governor, 1880 Pt. 2, 27 October, 1880 , No. 147, NAGA, ADM 1/1/51; and Gold Coast Despatches from Secretary of State to Governor, 1881 Pt. 2, 26 February, 1881, No. 267, NAGA, ADM 1/1/52.

58 C. 3386, Rowe to Kimberley, 17 October, 1881, Encl. 1 in No. 7. See also Johnson, Salaga Papers, Vol. 1, SAL/59/1. 
59 C. 3386, Rowe to Kimberley, 17 October, 1881, Encl. 1 in No. 7.

60 Johnson, "Slaves of Salaga," 356.

61 Johnson, The Salaga Papers, Vol. I, SAL/12/1.

62 Johnson "Slaves of Salaga," 349-355.

63 See note 31 .

${ }^{64}$ For the Salaga-Voltaic districts route, see Johnson, Salaga Papers Vol. I. SAL 61/1 1880-81; and C. 3386, Rowe to Kimberley, March 27, 1882, No, 36. For a fuller account, see Marion Johnson, "Ashanti East of the Volta" in Transactions of the Historical Society of Ghana, 8 (1965), 33-59.

65 Traders from Yorubaland traveled to Accra from where they undertook a 30-day march to Salaga. They accepted the English silver coin. See C. 3386, Rowe to Kimberley, 16 January, 1882, Encl. in No. 18; C. 3386, Rowe to Kimberley, 10 May, 1882, Encl. 2 in No. 42; and Young to Derby, 21 April, 1884, Encl. in No. 41 in Further Correspondence Respecting the Affairs of the Gold Coast, Parliamentary Papers, 1885, C. 4477 (hereafter C. 4477).

66 Gold Coast Despatches from Governor to Secretary of State, 1876-77, 10 February, 1877, No. 78, NAGA, ADM 1/1/21. See also C. 3386, Rowe to Kimberley, 10 May, 1882, Encl. 2 in No. 42.

67 For the kola and salt trading activities of the "Hausa" in Akyem in ca.1901-ca.1904, see Palaver Book, January 1901-April 1904, NAGA, ADM 11/1/1773. Splendid materials abound in the Accra, Koforidua, Cape Coast, Sekondi regional archives on the Hausa diaspora from the latter part of the nineteenth century to about the $1940 \mathrm{~s}$. A cursory glance through these documents indicates that the "Hausas" were not transient soldiers and traders, but had settled communities in what is now modern Ghana from the late nineteenth century.

68 See C. 6053, Hodgson to Knutsford, 17 February, 1890, Encl. 1 in No. 59.

69 NAGA, ADM 1/2/21, 15 September, 1876, No. 188; and NAGA, ADM 1/2/26, 18 March, 1882, No. 83.

${ }^{70} \mathrm{See}$, for example, C. 4906 Firminger to Governor, 15 May, 1886, Encl. in No. 24.

71 See, for example, Ibid; The African Times, 1 July, 1876; The African Times, 1 November, 1879; Gold Coast Despatches from Governor to Secretary of State, 1879-80, 12 February, 1880, No. 47, NAGA ADM 1/2/23; and The Western Echo (Cape Coast), 10-27 January, 1887.

72 Gold Coast Despatches from Governor to Secretary of State, 1876-77, 10 February, 1877, No. 78, NAGA, ADM 1/1/21; Anti-Slavery Reporter, November 1878,123 ; C. 3386 , Rowe to Kimberley, 16 January, 1882, Enclosure in No. 18; and C. 6053, Hodgson to Knutsford, 17 February, 1890, Encl. 1 in no. 59. 
${ }^{73}$ Fynn, Oral Traditions of the Fante States No. 1 Abrem, 10-13; and Fynn, Oral Traditions of the Fante States No. 5 Abeadzie, 13-14.

74 Ibid.

75 Ibid.

76 Paul Lovejoy, Transformations in Slavery (Cambridge, 1983).

${ }_{77}$ See, for example, The African Times, 23 October, 1863, 14; and Johnson, Salaga Papers Vol. I. SAL 61/1.

78 See, for example, C. 4477, Young to Derby, 18 January, 1885, No. 61; NAGA, ADM 11/1/1770; Criminal Record Book, October 1886-June 1888, Case dd. 19/1/1888, NAGA SCT 17/5/9; C. 6053 Cole to Hughes, 7 August, 1889, Encl. 6 in No. 59; C. 6053, Williams to Hughes, 30 January, 1890, Encl. 22 in No. 59; and Criminal Record Book, September 1891November 1892, Case dd. 13/4/1892, NAGA, SCT 17/5/12.

${ }^{79}$ See, for example, Greene, Gender.

80 The African Times, 22 November, 1862. See also The African Times, 23 April, 1863; The African Times, 23 October, 1863; The African Times, 23 November, 1863, The African Times, 23 February, 1864; and The African Times, 23 July, 1864.

81 The African Times, 23 October, 1863.

82 The African Times, 23 February, 1873.

${ }^{83}$ The African Times, 23 October, 1876.

84 J.C. Christaller, "Recent Explorations in the Basin of the Volta (Gold Coast) by Missionaries of the Basel Missionary Society" in Royal Geographical Society, 8 (1886), 250.

85 The African Times, 22 November, 1862; and The African Times, 23 April, 1863. 86 Ibid.

87 Gold Coast Despatches from Governor to Secretary of State, 1880-81, 5 April, 1880, No. 100, NAGA, ADM 1/2/24; C. 4477, Young to Derby, 18 January, 1885, No. 61; C. 4477, Campbell to Colonial Secretary, 17 January, 1885 , Encl. 1 in No. 65 ; C. 4477 , Young to Derby, 18 January, 1885 , No. 64 ; C. 4477 , Young to Derby, 19 January, 1885 , No. 65 ; C. 4477 , Evans to the Governor, 19 January, 1885, Encl. 1 in No. 65; C. 4477, Memo for the Honorable F. Evans in re Geraldo de Lima, 19 January, 1885, Encl. 2 in No. 65; and C. 4906, Griffith to Carnarvon, 5 June, 1885, No. 1.

88 See, for example, The African Times, 23 June, 1865; The African Times, 23 August, 1865; The African Times, April 23, 1866; The African Times, 23 September, 1866; The African Times, 23 January, 1867; The African Times, 23 September, 1867; The African Times, 23 September, 1871; Admiralty to Colonial Office, 19 June, 1874, Encl. in No. 65 in Correspondence Relating to the Affairs of the Gold Coast, Parliamentary Papers, 1875, C. 
1140 (hereafter C. 1140); C. 1140, The Officer Administering the Government to Carnarvon, 23 June, 1874, No. 61; and C. 4477, Dudley to Colonial Secretary, February, 1883, Encl. in No. 7.

${ }^{89}$ C. 4477 , Subject - Geraldo De Lima, 10 January, 1885, Encl. 3 in No. 65.

${ }^{90}$ For the anarchy and the devastating effects of the war, see for example, Jenkins, $B M C$, Muller to Basel May 28, 1888 (First Report as Missionary in Charge of Anum District). No. II.107, 248. For a detailed account of the Asante-Anlo-Ewe war of 1869, see Donna Maier, "Asante War Aims in the 1869 Invasion of Ewe," in Enid Schildkrout, ed., The Golden Stool: Studies of the Asante Center and Periphery (New York, 1987), 232-244. See also The African Times, 23 September, 1871.

91 See, for example, The African Times, 1 October, 1877; and C. 4477, Subject - Geraldo De Lima, 19 January, 1885, Encl. 3 in No. 65.

92 The African Times, 23 February, 1873.

93 Johnson, Salaga Papers, Vol. 1, SAL/54/1.

94 C. 1140, The Officer Administering the Government to Carnarvon, 23 June, 1874, No. 61; Gold Coast Despatches from Governor to Secretary of State, 1882, 20 March, 1882, No. 91, NAGA ADM 1/2/26. See also Gold Coast Despatches from Secretary of State to Governor, 1877, 9 March, 1877, No. 410, NAGA, ADM 1/1/43; Gold Coast Despatches from Secretary of State to Governor, 1880 Pt. 1, 8 June, 1880, No. 35, NAGA, ADM 1/1/50; Gold Coast Despatches from Secretary of State to Governor, 1881, 23 December, 1881, No. 560, NAGA, ADM 1/1/53; and The African Times, 1 April, 1885.

95 See, for example, Derby to Rowe, 31 December, 1883, No. 48 in Further Correspondence Regarding the Affairs of the Gold Coast, Parliamentary Papers, 1884 , C. 4052 (hereafter C. 4052).

96 The African Times, 22 November, 1862; The African Times, 23 April, 1863; The African Times, 23 February, 1873; C. 1402, Carnarvon to Strahan, 14 August, 1875, No. 62; Gold Coast Despatches from Governor to Secretary of State, 1876-77, 13 March, 1877, No. 79, NAGA, ADM 1/1/21; Gold Coast Despatches from Governor to Secretary of State, 1882, 6 March, 1882, No. 68, NAGA, ADM 1/2/26; C. 4052, Derby to Rowe, 31 December, 1883, No. 48; Gold Coast Despatches from Secretary of State to Governor, 19 December, 1883-26 May, 1884, 21 January, 1884, No. 45, NAGA, ADM 1/2/36; C. 6354, Griffith to Knutsford, 26 January, 1891 , No. 7; C. 6053, MacMunn to Hughes, November 5, 1889, Encl. 3 in No. 59; C. 6053, Redwar to Hughes, 27 August, 1889, Encl. 17 in No. 59; and The Times (London), 1 September, 1890.

97 According to Basel missionary Muller, in the 1880s, he informed the district commissioner in charge of Anum about a case involving the chief 
of Anum, who had received 7 boys as pawns from a debtor in Buem, but the district commissioner explained that the pawns "were in good hands and took no action." See Jenkins, $B M C$, Muller to Basel dd. 17 September, 1895 No. I.49-50, 341 a.

98 Ibid. Muller's report was a comment on the Basel Committee Protocoll [sic] of 1895 , paragraph 34 which was a part of a reply to questions on slavery and pawning put by the Twi District Conference and to the Synod in 1895.

99 Jenkins, $B M C$, Clerk's Report for the Year 1891 dd. 15 January, 1890 , No. II.147, 266. See also Jenkins, $B M C$, Clerk's Report on a Journey in Buem etc., dd. 15 March, 1890, Nos.II. 129-130, 267.

100 Jenkins, $B M C$, Clerk's Report for the Second Quarter 1896 dd. 31 July, 1896, 354.

101 Jenkins, $B M C$, Muller to Basel dd. 20 March, 1897, No. II.184, 376. According to Muller, another missionary, Martin had pointed out that the German colonial authorities freed slaves by paying compensation to slave holders and then forcing the freed slaves to work for the colonial government. Martin had concluded that this was not popular with women and old people.

102 Jenkins, $B M C$, Mischilisch to Basel dd. 20 December, 1896, No. II.192, 361; and Jenkins, $B M C$, Peregaux Correspondence dd. 1 March, 1896, 345. 103 Jenkins, $B M C$, Peregaux Correspondence, dd. 1 March, 1896, 345.

104 Jenkins, $B M C$, Muller to Basel dd. 20 March, 1897. No. II.184, 376.

105 Johnson, "Ashanti East of the Volta," 42, notes that salt and slaves were the main items of trade passing by this route [Volta-Krakye] before 1874." 106 Jenkins, $B M C$, Martin to Basel dd. 18 November, 1896, No. II.184, 359.

107 Ibid.

108 The African Times, 2 October, 1876.

109 The African Times, 23 May, 1864; The African Times, 26 July, 1864; and The African Times, 12 April, 1877.

110 The African Times, 1 August, 1877; The African Times, 1 December, 1877; The African Times, February 1, 1879; The African Times, 1 March, 1880; and The African Times, 1 April, 1885; and C. 6053, Rich to Ferris, 4 March, 1890, Encl. 3 in No. 60.

111 Johnson, "Slaves of Salaga."

112 See, for example, Anti-Slavery Reporter, 7 November, 1878; and C. 4477, Subject - Geraldo De Lima, 19 January, 1885, Encl. 3 in No. 65.

113 See, for example, Gold Coast Despatches from Secretary of State to Governor, 1876, 18 July, 1876, No. 298, NAGA, ADM 1/1/42; and Gold Coast Despatches from Secretary of State to Governor, 1877, January [nd], 1877, No. 375, NAGA, ADM 1/1/43. 
114 See, for example, The African Times, 23 November, 1864; The African Times, 23 December, 1864; C. 6053, Williams to Hughes,

January 20, 1890, Encl. 22 in No. 59; C. 6053, Travers to Turton, 17 February, 1890, Encl. 33 in No. 59; and Jenkins, $B M C$, Mohr A Postscript dd. 11 May, 1888, (in Akyem 1888-1914), 10.

115 See, for example, P.F.W. Bartle, "Inequality and Cyclical Migration: Changing Patterns of Traditional Society" in Ghana Journal of Sociology, 12, 1 (1978/9), 31-33; and Edward Reynolds, "The Slave Trade, Slavery and Economic Transformation of the Gold Coast in the Nineteenth Century" in Serge Daget, ed., De La Traite L'Esclavage (Nantes, 1988) 580 .

116 Reynolds, "Slave Trade," 580.

117 Akurang-Parry, "Missy Queen," chapter 8.

118 See note 1.

119 See C. 6010 , Colonial Office to Foreign Office, June 29, 1889, No. 47; and C. 6010, Firminger to Colonial Office, 30 April, 1889, Encl. in No. 47. 120 The reference to the information was the circular dated 26 July, 1889, copies of which were sent to all district commissioners requesting them to furnish the office of the governor with information on whether slave-dealing existed as Firminger had reported. See C. 6053, Hughes to MacMunn, 26 July, 1889, Encl. 2 in No. 59.

121 C. 6053 , MacMunn to Hughes, 5 November, 1889, Encl. 3 in No. 59. It should be emphasized that controversy erupted over MacMunn's report and his handling of slave-dealing cases. Both Acting Governor Hodgson and Governor Griffith suggested in their respective reports that MacMunn's report was untrue, and that he was an upstart, inexperienced, and irresponsible. See C. 6053, Hodgson to Knutsford, 17 February, 1890, Encl. 1 in No. 59; and C. 6354, Griffith to Knutsford, 26 January, 1891, No. 7. See also $C$.

6354, Peregrine to Colonial Secretary, 7 October, 1890, Encl. 1 in No. 7. 122 C. 6010 , MacMunn to Hughes, Encl. 5 in No. 59.

123 The probable "Northern" names were Issah, Drisue [Iddrisu], Aminah and Addisa. The Akan names were Quow Agima [Agyemang ?] and Edifour [Eduful ?], while the Ga-Adangbe names were Quacoe Pone [Quarcoopome], Cudjoe, Kpanu [Paa Nii ?], Oyinor, and Tarwiah. For similar patterns, see also NAGA, SCT 17/5/12, September 1891-November 1892, Case dd. 3/3/1891; and Criminal Record Book, October 1889August 1890, Case dd. 23/3/1890, NAGA, SCT 17/5/9.

124 C. 6010 , MacMunn to Hughes, Encl. 5 in No. 59. The probable Akan names included Adjua [Adwoa], Affiah (may be Ewe) [Afua], Quamina [Kwamena], Abla (may be Ewe) Abena, and Accosua [Akosua]. The GaAdangbe names were Ladi and Dadaye. 
125 Ibid.

126 The Ga-Adangbe names were Kasu, Dadaye, Korkor and Okine.

127 See Akurang-Parry, "Administration of Abolition Laws," 158-159.

128 See C. 6010 ; C. 6053 ; and C. 6354.

129 C. 6053 , Encl. 5 in No. 59. See also Criminal Record Book, October 1889-August 1890, Case dd. 24/3/1890, NAGA, SCT 17/5/90; and Criminal Record Book, October 1889 - August 1890, Case dd. 17/4/1890, NAGA, SCT 17/5/90.

$130 \mathrm{See}$, for example, Johnson, Salaga Papers, Vol. I SAL/8/5.

131 See, for example, C. 6010 , Firminger to Colonial Office, 30 April, 1889, Encl. in No. 47.

132 See, for example, C. 6053 , Encl. 5 in No. 59 ; C. 6053 , Encl. 7 in No. 59; C. 6053, Encl. 9 in No. 59; and C. 6053, Encl. 21 in No. 59.

133 C. 6053 , Encl. 5 in No. 59. See also C. 6354 , Griffith to Knutsford, January 26, 1891, No. 7 .

134 I use notables to denote influential slave dealers and holders, some of them women who had their way with colonial officials. See C. 6354 , The APS to Colonial Office, 20 August, 1890, No. 1; C. 6354, The APS to Colonial Office, September 1, 1890, No. 4; C. 6354, The APS to Colonial Office, 15 April, 1891, No. 11; C. 6354, Griffith to Knutsford, 26 January, 1891, No. 7; C. 6354, Peregrine to the Colonial Secretary, 7 October, 1890 , Encl. 1 in No. 7; and The Times, (London), 1 September, 1890. For some chiefs who did not suffer the brunt of anti-slavery ideology, see for example, King Kwame Fori of Akuapem in Rev. E. Sampson, History of Aquapim and Akropong (Accra, 1908), 12; and for the acquittal of Amoako Atta I of Akyem Abuakwa by an African educated jury, see for example, Gold Coast Despatches from Governor to Secretary of State, 1880-81, May 25,1880 , No. 160, NAGA, ADM 1/2/24; and Jenkins, $B M C$, General Correspondence of the Year 1880 Referring to Kibi, Eisenschmid, dd. 20 May, 1880 , No. 4.

135 See C. 6354 , The APS to Colonial Office, 20 August, 1890, No. 1.

136 See C. 6354 , The APS to Colonial Office, 20 August, 1890, No. 1; C. 6354, The APS to Colonial Office, 1 September, 1890 , No. 4 ; C. 6354, The APS to Colonial Office, 15 April, 1891, No. 11; C. 6354, Griffith to Knutsford, 26 January, 1891, No. 7; C. 6354, Peregrine to the Colonial Secretary,7 October, 1890, Encl. 1 in No. 7; and The Times, (London), 1 September, 1890. 